\title{
Degradation of 2,6-dimethylpyridine by Arthrobacter crystallopoietes
}

\author{
Fatima M. Khasaeva1', Igor A. Parshikov² and Evgeny I. Zaraisky² \\ ${ }^{1}$ Department of Microbiology, Kabardino-Balkarian State Agrarian University of V.M. Kokov, \\ Nalchik, Russia \\ ${ }^{2}$ Institute of Applied Mechanics, Russian Academy of Sciences, Moscow, Russia
}

(Received 15 April, 2016; accepted 5 June, 2016)

\begin{abstract}
Degradation of pyridines in waste water is an important issue for chemical and pharmaceutical industries. The biodegradation of 2,6-dimethylpyridine was investigated by the bacterium Arthrobacter crystallopoietes KM-4, which resulted in the formation of three metabolites: 2,6-dimethylpyridin-3-ol, 2,6-dimethylpyridin3,4-diol, and 2,4-dioxopentanoic acid.
\end{abstract}

Key words : Biodegradation, 2,6-dimethylpyridine, Arthrobacter crystallopoietes, Bacteria

\section{Introduction}

The increase of chemical industries has led to the accumulation of polluting substances in the biosphere. Pyridine and its derivatives are some of these pollutants that have invaded our biosphere. They are a class of important heterocyclic compounds, that are formed during coal processing and found in the waste water of chemical plants, plants producting synthetic rubber, plastics, and dyes (Dobson et al., 1985; Pereira et al., 1988; Rogers et al., 1985). Pyridines are widely used as solvents and reactants in the production of agricultural chemicals, such as herbicides and also pharmaceuticals (Kaiser et al., 1996; Modyanova et al., 1999; Parshikov, 2015 a,b).

\section{Materials and Methods}

The strain of bacteria used in this research was Arthrobacter crystallopoietes KM-4, obtained from the microbial collection from the Department of Micro- biology, Moscow State University.

To study of the degradation of 2,6dimethylpyridine (I) the synthetic medium, having the following composition was used (g/L): $\mathrm{Na}_{2} \mathrm{HPO}_{4}$ - 4.26; $\mathrm{KH}_{2} \mathrm{PO}_{4}-2.65 ; \mathrm{MgSO}_{4} \cdot 7 \mathrm{H}_{2} \mathrm{O}-0.2$; $\mathrm{FeSO}_{4} \cdot 7 \mathrm{H}_{2} \mathrm{O}-0.01 ; \mathrm{CaCl}_{2} \cdot 2 \mathrm{H}_{2} \mathrm{O}-0.02 ; \mathrm{MnSO}_{4} \cdot \mathrm{H}_{2} \mathrm{O}$ $-0.002 ; \mathrm{Na}_{2} \mathrm{MoO}_{4}-0.001$; deionised water $-1 \mathrm{~L} ; \mathrm{pH}$ 7.0 - 7.2. Cultures of A. crystallopoietes KM-4, were grown in $750 \mathrm{~mL}$ flasks containing $200 \mathrm{ml}$ of medium on a shaker $(200 \mathrm{rpm} / \mathrm{min})$ at $28-30^{\circ} \mathrm{C}$. The 2,6-dimethylpyridine served as the carbon and nitrogen source and was added to the the liquid medium at a concentration of $2.0 \mathrm{~g} / \mathrm{L}$ The degradation process lasted 36 hours.

Degradation products were extracted with chloroform and after evaporation were dissolved in 0.5$1.0 \mathrm{~mL}$ of ethanol. Separation of the degradation products was performed on "Silufol UV-254" (DCAlufolies Kieselgel $60 \mathrm{~F}_{254}$, Merck, Germany) chromatography plates. The solvent systems used for the separation were as follows:

1. Chloroform - methanol (20:3); 
2. Chloroform - acetone - ethanol (7:2:2);

3. Ethanol - ammonia - water (20:1:4);

4. Ethyl acetate - petroleum ether (5:1).

Chromatograms were visualized by UV light or iodine vapors. For preparative isolation of individual products column chromatography was used (Silicagel L 40/100, Chemapol, Czech Republic) using solvent system 3 , and preparative thin layer chromatography (TLC) using solvent systems 2, 3 and 4 .

Electron ionization (EI) mass spectrometry was performed at an electron energy of $70 \mathrm{eV}$ on the Finigan MAT-4615 (Khasaeva and Parshikov, 2015). IR (infrared) spectra were recorded using a Thermo Nicolet IR 300 FT/IR spectrometer on a germanium crystal as neat solids or liquids.

\section{Results}

Investigation of the degradation of 2,6dimethylpyridine (I) by A. crystallopoietes KM-4 was demonstrated in a growing culture of bacteria. Analysis of UV spectra $\left(\lambda_{\max }=268 \mathrm{n} \mu\right)$ showed that the 2,6-dimethylpyridine was completely degraded by the bacterium $A$. crystallopoietes KM-4, at the end of the stationary phase (30 hours). Degradation products were detected by TLC. Synthetic compounds were used as controls to compare with the expected metabolites of degradation of 2,6dimethylpyridine.

In the initial phase of growth, compound II was present in trace amounts. The maximum amount of this substance was detected after 15 hours of growth. Compound II was completely gone after 24 hours. It was evident, that the bacteria was able to use this compound as a growth substrate. Based on mass spectral analysis the compound II was identified as 2,6-dimethylpyridin-3-ol (Fig. 2, Table 1). The presence of the hydroxy group also was confirmed by the absorption band in the IR spectrum, $3510 \mathrm{~cm}^{-}$ ${ }^{1}$ (Table 1).

Compound III (Fig. 1) was not isolated during growth of A. crystallopoietes KM-4 in the presence of 2,6-dimethylpyridine. Instead, it was isolated during growth of $A$. crystallopoietes KM-4 in the presence of 2,6-dimethylpyridin-3-ol. This means that during the microbial degradation of 2,6dimethylpyridine, compound III was present in the supernatant, but its amount was not sufficient for isolation and identification purposes. Based on mass spectral analysis, compound III was identified as 2,6-dimethylpyridin-3,4-diol (Fig. 2, Table 1).

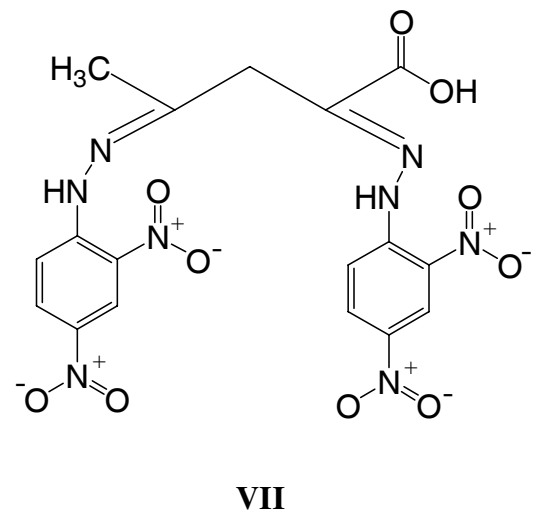

Fig. 1. The structure of VII - was identified as (2E,4E)-2,4bis[2-(2,4-dinitrophenyl) hydrazinylidene] pentanoic acid.

Table 1. Mass spectral identities of intermediate compounds produced by degradation 2,6-dimethylpyridine by A. crystallopoietes KM-4

\begin{tabular}{|c|c|c|}
\hline Compounds & Mass spectra: $m / z$; Relative abundance, $\%$ & $\begin{array}{c}\text { IR spectra(neat) } \\
\lambda_{\max }\left(\mathrm{cm}^{-1}\right)\end{array}$ \\
\hline II & $\begin{array}{l}123(73) \mathrm{M}^{+} 122(12)(\mathrm{M}-\mathrm{H})+, 108(6)\left(\mathrm{M}-\mathrm{CH}_{3}\right)^{+} \\
95(20)(\mathrm{M}-\mathrm{CO})^{+}, 94(100)(\mathrm{M}-\mathrm{CHO})^{+} \\
81(7)\left(\mathrm{MCH}_{3}-\mathrm{HCN}\right)^{+}, 80(11)\left(\mathrm{M}-\mathrm{CH}_{3}-\mathrm{CO}\right)^{+}\end{array}$ & 3510 \\
\hline III & $\begin{array}{l}139(51)+(\mathrm{M}), 111(20)(\mathrm{M}-\mathrm{CO})+, 110(100)\left(\mathrm{M}-\mathrm{CHO}^{\circ}\right)^{+}, \\
96(7)\left(\mathrm{M}-\mathrm{CO}-\mathrm{CH}_{3}\right)+, 95(5)\left(\mathrm{M}-\mathrm{CHO}-\mathrm{CH}_{3}\right)^{+} \\
491(2)(\mathrm{MH})^{+}, 474(2)(\mathrm{MH}-\mathrm{OH})+, 447(2)\left(\mathrm{MH}-\mathrm{CO}_{2}\right)^{+}, \\
266(19)\left(\mathrm{CH}_{2}-\mathrm{C}(\mathrm{COOH})-\mathrm{N}_{2}-\mathrm{Ar}^{*}\right)^{+}, \\
237(9)\left(\mathrm{CH}_{3}-\mathrm{C}\left(\mathrm{CH}_{2}\right)-\mathrm{N}_{2} \mathrm{H}-\mathrm{Ar}\right)^{+}, \\
223(9)\left(\mathrm{CH}_{3}-\mathrm{C}^{+} \mathrm{N}^{+}-\mathrm{NH}-\mathrm{Ar}\right), 1 \\
83(42)\left(\mathrm{NH}_{2}-\mathrm{Ar}\right)+; 182(100)(\mathrm{NH}-\mathrm{Ar})^{+}, 167(35)(\mathrm{Ar})^{+}\end{array}$ & $\begin{array}{l}3225 \\
3490\end{array}$ \\
\hline
\end{tabular}

$\mathrm{Ar}^{*}-2,4\left(\mathrm{NC}_{2}\right)_{2} \mathrm{C}_{6} \mathrm{H}_{3}$ 
<smiles>Cc1cccc(C)n1</smiles><smiles>CC(=O)CC(=O)C(=O)OCCCCCCCC(=O)O</smiles>

Fig. 2. The process of catabolism of 2,6-dimethylpyridine (I) by strain A. crystallopoietes KM-4. II - 2,6dimethylpyridin-3-ol; III - 2,6-dimethylpyridin-3,4-diol; IV and V - possible intermediates; VI - 2,4dioxopentanoic acid; VIII - acetamide.

During the chromatography of acidified extract of the supernatant was found the compound VI (2,4dioxopentanoic acid) which was giving the reaction with 2,4-dinitrophenylhydrazine. This compound was isolated by preparative TLC as a thick oil. After treatment of compound VI with a solution of 2,4dinitrophenylhydrazine, dihydrazone (VII) was formed (Fig. 1) and then repeatedly purified by preparative chromatography. The maximum amount of compound VI was detected in culture media after of 6-9 hours of cultivation, and then, with the growth of the A. crystallopoietes KM-4, the content of the compound VI in the medium was gradually decreased. Based on mass spectral data, the compound VII was identified as (2E,4E)-2,4-bis[2-(2,4dinitrophenyl) hydrazinylidene] pentanoic acid (Table 1). The presence of compound VI in the supernatant showed that the pyridine ring, presumably containing two $\mathrm{OH}$ groups, was opened between the second and third carbon atom.

\section{Discussion}

Based on the analysis of the isolated products, it can be concluded that nitrogen is included in the acetamide molecule (VIII) after hydrolysis of compound $\mathrm{V}$ (Fig. 2). Acetamide was not detected in the supernatant, possibly because $A$. crystallopoietes KM-4 quickly uses it as a source of carbon and nitrogen.

In the biodegradation process of 2,6dimethylpyridine the formation of ammonia was not shown also.

Based on the analysis of the results and data from the literature (Watson et al., 1974), we offer a pathway of catabolism of 2,6-dimethylpyridine (I) by A. crystallopoietes KM-4 (Fig. 2).

Studies have shown that the bacterium $A$. crystallopoietes KM-4 has highly destructive properties against 2,6-dimethylpyridine $(2.0 \mathrm{~g} / \mathrm{L})$ and is capable of utilizing it as a carbon and nitrogen source within a relatively short amount of time (36 h). It is has been shown that the primary reaction of enzyme systems in bacteria is a hydroxylation (Khasaeva et al., 2016; Parshikov et al., 2015) of the 2,6-dimethylpyridine, and then the disclosure of a ring which leads to the formation of compounds such as 2,4-dioxopentanoic acid and acetamide. The highly destructive properties allowing for the complete consumption of the 2,6-dimethylpyridine, allows for the recommendation of the bacterium $A$. crystallopoietes KM-4 for use in the treatment of industrial waste water from alkylpyridines.

\section{Acknowledgement}

We thank Dr. P. B. Terent'ev for assistance in interpretation of mass spectra. 


\section{References}

Dobson, K.R., Stephenson, M., Greenfield, P.F. and Bell, P.R.F. 1985. Identification and treatability of organics in oil shale retort water. Water Research. 19 (7): 849-856.

Kaiser, J.P., Feng, Y. and Bollag, J.M. 1996. Metabolism of pyridine, qunoline, acridine and derivatives under aerobic and anaerobic conditions. Microbiological Reviews. 60 (3): 483-498.

Khasaeva, F.M. and Parshikov, I.A. 2015. Biodegradation of 2,4-dimethylpyridine by Rhodococcus erythropolis. International Journal of Nanobiotechnology and Pharmacy. 1: 4-11.

Khasaeva, F.M., Parshikov, I.A., Zaraisky, E.I. 2016. Biodegradation of 4-methylpyridine by Àrthrobacter sp. Asian Journal of Microbiology, Biotechnology and Environmental Sciences. 18 (1): 75-77.

Modyanova, L.V., Duduchava, M.R., Piskunkova, N.F., Grishina, G.V., Terentyev, P.B. and Parshikov, I.A. 1999. Microbial transformations of piperideine and pyridine derivatives. Chemistry of Heterocyclic Com- pounds. 35 (5): 580-586.

Parshikov, I.A. 2015a. Microbial Conversions of Nitrogenous Heterocycles. Editus, Moscow. 130.

Parshikov, I.A. 2015b. Microbial Conversions of Terpenoids. Editus, Moscow. 100.

Parshikov, I.A., Woodling, K.A. and Sutherland, J.B. 2015. Biotransformations of organic compounds mediated by cultures of Aspergillus niger. Applied Microbiology and Biotechnology. 99 (17): 6971-6986.

Pereira, W.E., Rostand, C.E., Leiker, T.J., Updergraff, D.M. and Beennett, J.L. 1988. Microbial hydroxylation of quinoline in contaminated groundwater: evidence for incorporation of the oxygen atom of water. Applied and Environmental Microbiology. 54 (3) : 827-829.

Rogers, J.E., Riley, R.G, Li, S.W., O’Malley, M.L. and Thomas, B.L. 1985. Microbial transformation of alkylpyridines in groundwater. Water, Air and Soil Pollution. 24 (4): 443-454.

Watson, G.K., Houghton, C. and Cain, R.B. 1974. Microbial metabolism of the pyridine ring. The metabolism of pyridine-3,4-diol (3,4-dihydroxypyridine) by Agrobacterium sp. Biochemical Journal. 140 (2): 277292. 